\title{
PRELIMINARY EXPERIMENTS ON POTENTIAL USE OF SALT-WATER BATTERY FOR CHEAP ELECTRIC STORAGE: WORK IN PROGRESS
}

\author{
YUNITA UMNIYATI ${ }^{1 *}$, KEVIN INDRA WIJAYA ${ }^{1}$, ERICSON SINAGA ${ }^{1}$, VICTOR \\ CHRISTIANTO $^{2}$ \\ ${ }^{1}$ Department Mechatronics, Swiss-German University, The Prominence Tower Alam Sutera, Jl \\ Jalur Sutera Bar. No.Kav 15, RT.003/RW.006, Panunggangan Tim., Kec. Pinang, Kota \\ Tangerang, Banten 15143, Indonesia, Telp. +6221-29979556 \\ ${ }^{2}$ Institut Pertanian Malang, Malang, Indonesia \\ *email : victorchristianto@gmail.com
}

\begin{abstract}
Abstrak. Penggunaan listrik yang efektif dari sumber terbarukan membutuhkan sistem penyimpanan energi listrik stasioner (EES) berskala besar dengan baterai berdensitas tinggi dan murah yang dapat diisi ulang. Sementara baterai yang menggunakan litium, kadmium, timbal-asam dll telah banyak digunakan, terdapat sumber alternatif yaitu air asin yang cukup melimpah di alam dan dikenal sebagai elektrolit. Kami melaporkan serangkaian percobaan pendahuluan tentang potensi penggunaan air asin sebagai sumber murah baterai terbarukan dengan berbagai jenis logam sebagai anoda dan katoda. Tujuan dari percobaan ini adalah untuk mengetahui kombinasi anoda dan katoda mana yang mampu menghasilkan kinerja terbaik dari segi tegangan listrik. Diharapkan percobaan ini akan mengarah pada implementasi praktis dalam waktu dekat.
\end{abstract}

Kata kunci: energi terbarukan, penyimpanan energi listrik, aki air laut, aki air asin, teknologi aki

\begin{abstract}
The effective use of electricity from renewable sources requires large-scale stationary electrical energy storage (EES) systems with rechargeable high-energy-density, cheap batteries. While batteries using lithium, cadmium, lead-acid etc. have been widely used, there is an alternative source i.e. salt-water which is quite abundant in nature and known as electrolyte. We report a series of preliminary experiments on potential use of salt-water as cheap source of renewable battery with various kind of metals as anode and cathode. The purpose of these experiments is to find out which combination of anode and cathode is capable to generate the best performance in terms of electric voltage. It is hoped that these experiments will lead to practical implementation in the near future.
\end{abstract}

Keywords: renewable energy, electrical energy storage, seawater batteries, salt water battery, battery technology

\section{Introduction}

As it is known, the majority of energy usage in the world is predominated by fossil fuels. But it has resulted in many environmental problems, including ozone layers problem. Renewable energy sources have been promoted as an alternative to such fossil fuel sources. Among many kinds of renewable energy sources, solar energy has become the most favorite in many counties, along with water and wind. They are called WWS (wind, water, solar) energy. 
Nonetheless, solar cells or photovoltaic energy have their own drawbacks, such as their relatively high initial cost. Furthermore, they need to be integrated with electric energy storage such as batteries with large capacities.

Therefore, we need a more cost-efficient electric energy storage systems. One of the options is salt-water power, which comes from the basic known fact of electrolytic nature of salt-water. Furthermore, it is known that more than $70 \%$ of Earth surface is covered with water, and $97 \%$ of them is in the form of salt-water. Furthermore, in Indonesia, a large part of its region is covered by water, that would suggest that salt-water is in abundant supply.

From innovation point of view, we consider it is time to begin research not only in conventional renewable energy technologies (like WWS, geothermal etc.), but also in a new type of renewable energy, which we prefer to call: ART (appropriate renewable technologies). In this regard, we can point out a few examples, such as: solar focused power plant or Alfredo Moser's bottle lamp. In recent years, there is intensive ongoing research in rechargeable seawater battery (SWB).

Despite several existing studies on possibilities to implement salt-water battery systems [1-3], few seem to have been done in the context of investigating its potential use for low-budget grid-scale electric storage (EESS). One of possible materials for EESS is using electro-chemicals. Electrochemical energy-storage technologies such as batteries and fuel cell are a method used to store electricity under a chemical form. The technologies differentiated by their energy storage mechanism. Batteries stores energy through electron transfer reaction, wherein the fuel cells store energy from external reactants fed to the cell. This storage technique benefits from the fact that both electrical and chemical energy share the same carrier, the electron.[9].

A few years ago, lead-acid battery is the most common electrochemical storage technology. Lead acid batteries commonly used for automotive applications because it is easy to find, easy to get, and also affordable. Nowadays, Li-ion batteries applications is increasing rapidly. Li-ion battery were made for portable electronics such as cellular phones, notebook, remote controls, etc.

There are two types of batteries, namely primary battery and secondary battery. Primary batteries are disposable meaning single use and cannot be recharged because the electrochemical reaction cannot be reversed. Secondary batteries are rechargeable, commonly found in devices such as smartphones, electronic tablets, vehicle batteries etc. [9].

$$
\varepsilon=-N\left(\frac{\Delta \phi \mathrm{M}}{\Delta t}\right)
$$

Where

$$
\begin{array}{ll}
N & =\text { Number of loops } \\
\Delta \phi \mathrm{M} & =\text { Change in magnetic flux } \\
\Delta t & =\text { Change in time } \\
\varepsilon & =\text { Induce voltage (emf) }
\end{array}
$$

As a matter of past experiment, let us tell our story by recalling an initial experiment that one of us (VC) conducted around 2006 [4], which shows a small voltage (around $0.2 \mathrm{~V}$ ) in distilled water after heating by the sun. However, at the moment we didn't have any theory to back up our result. 
Water has three phases, they are gas, liquid, and solid. However, Prof. Gerald Pollack found that there is the fourth phase of water named exclusive zone. EZ Water as known as an exclusive zone in water has been provided many convincing experimental demonstrations by Prof. Gerald Pollack. More recently, Gerald Pollack and his team in Washington University came up with an idea to build a water battery model.[5] Allan Widom et al. also came up with a theory of waterbattery system [6].

Later on, we figured it out that a salt-water mixture is likely to perform better compared to distilled water, because salt-water is known as natural electrolytes. In the meantime, we learn that there is growing interest on research on seawater battery, see for instance [7].

\section{Methods}

First, we report result of experiments that one of us carried out a series of lab-scale experiments in order to determine possible optimal configuration of salt-water battery system. These preliminary experiments focus on searching of the most effective metal for cathode-anode to generate voltage in salt-water liquid. Experiments also try to find out the most optimum mixture of salt-water [9].

Starting from research framework, there is research pathway that must be carried out. Existing condition will be described below to show that this research did not start from scratch. Then there is electrical design, explained on which method is suit for each objective. After that, component selection will be carried in components of design (including hardware and software). Last one, will be discussed on how to test the validity and reliability of the system in performance test. Furthermore, it will be discussed below.

\subsection{Venue and Time}

The experiment of Electric Energy storage system held in Swiss German University's Workshop in Alam Sutera, and it needs 3 months to do experiment and formulations.

\subsection{System Overview}

The system in this saltwater experiment is divided into 2 main sections. the first is, find a way to increase the voltage different by using series method including find the best material to conduct electricity. This experiment uses 10 series of salt water where 1 series produces $0.82 \mathrm{~V}$, therefore, the voltage source which can be obtained in this experiment is $8.2 \mathrm{~V}$ which is too low to charge a $12 \mathrm{~V}$ battery. Therefore, a dc-dc converter, or step-up module is needed to increase the voltage to be $12 \mathrm{~V}$. By using dc-dc converter can cause voltage drop, because it sacrifices the current. To keep the dc-dc converter works, this experiment must use the lowest input voltage on dc-dc converter in order to the step-up module still works even the voltage dropped. The second is to control the voltage different and current flows in the electrical system using voltage sensor Arduino and current sensor Arduino. The voltage, current and power will be displayed by 20x4 LCD. The Electrical Flowchart is shown in Figure 1. 


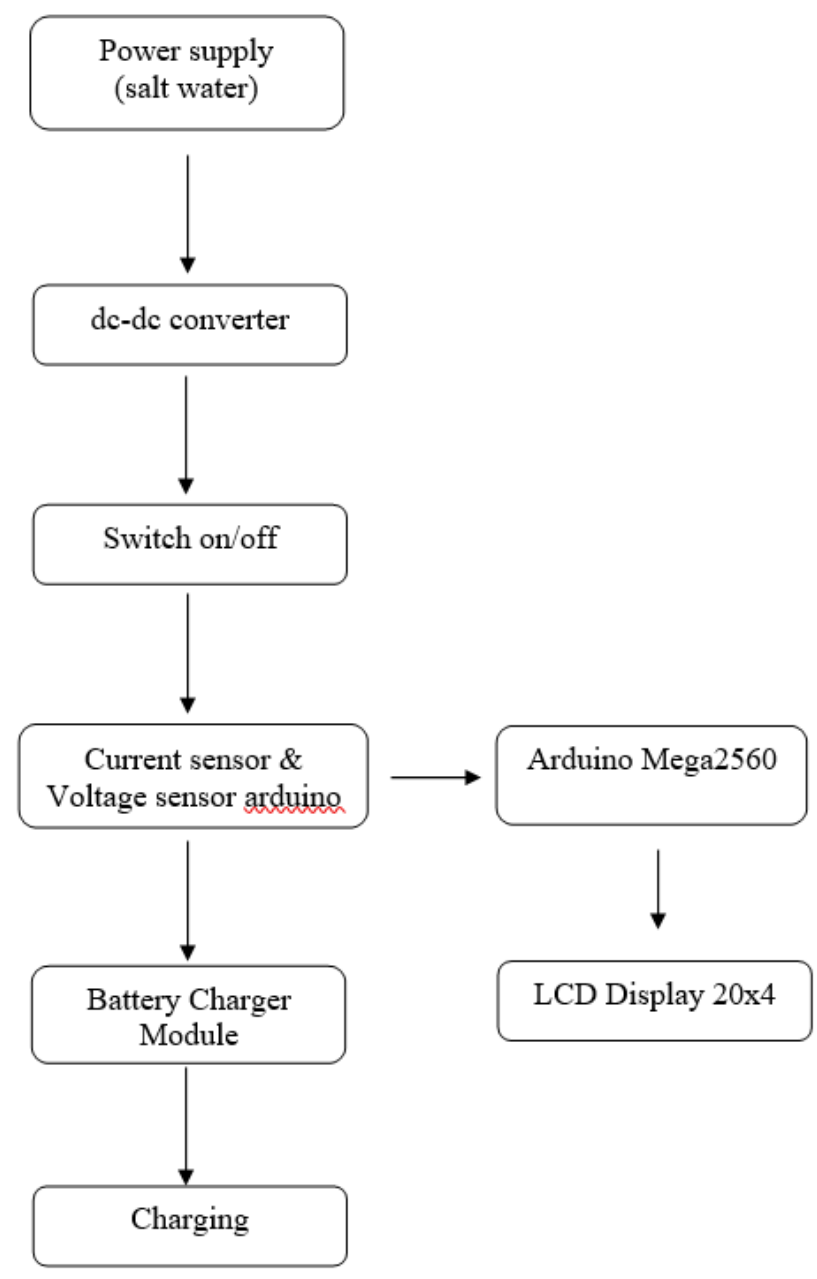

Figure 1. Electrical Flowchart

\subsection{Experimental Procedure}

Water that has been boiled into vapor and condensed back into liquid or Distilled water should be prepared in many types of container. The distilled water firstly at room temperature will be heat up using solar system focused on a loop. and then the water added with sea salt to make the water as electrolyte and then will be heat up again with solar system focused on a loop.

\subsection{Preliminary experimental results}

These preliminary experiments focus on searching of the most effective metal for cathode-anode to generate voltage in salt-water liquid. Experiments also try to find out the most optimum mixture of salt-water.

Electrolyte has a role to conduct ions between the anode and the cathode. Reversible chemical reactions at the electrodes are a vital part of any rechargeable cell. In a battery system there is a redox reaction, where reduction happens on the cathode and oxidation happens on the anode. Those reaction causes the movement of electrons which generate electricity (induced voltage) on a battery. Figure 2 illustrates a battery system [9]. 
$\mathrm{NaCl}$ (aqua) $\rightarrow \mathrm{Na}^{+}+\mathrm{Cl}^{-}$

$\mathrm{Zn}$ as cathode and $\mathrm{Cu}$ as anode

Cathode $\quad: 2 \mathrm{H}_{2} \mathrm{O}+2 \mathrm{e}^{-} \rightarrow 2 \mathrm{OH}^{-}+\mathrm{H}_{2}$

Anode $\quad: \mathrm{Cu} \rightarrow \mathrm{Cu}_{2}^{+}+2 \mathrm{e}^{-}$

Reaction $\quad: \mathrm{Cu}($ solid $)+2 \mathrm{H}_{2} \mathrm{O}$ (liquid) $\rightarrow \mathrm{Cu}(\mathrm{OH})_{2}$ (aqua) $+\mathrm{H}_{2}$ (gas)

In this saltwater experiment, the first material is the copper plate serves as anode and aluminum plate serves as cathode. The second material are the copper $(\mathrm{Cu})$ plate serves as anode and zinc plate serves as cathode to get the better current flow.
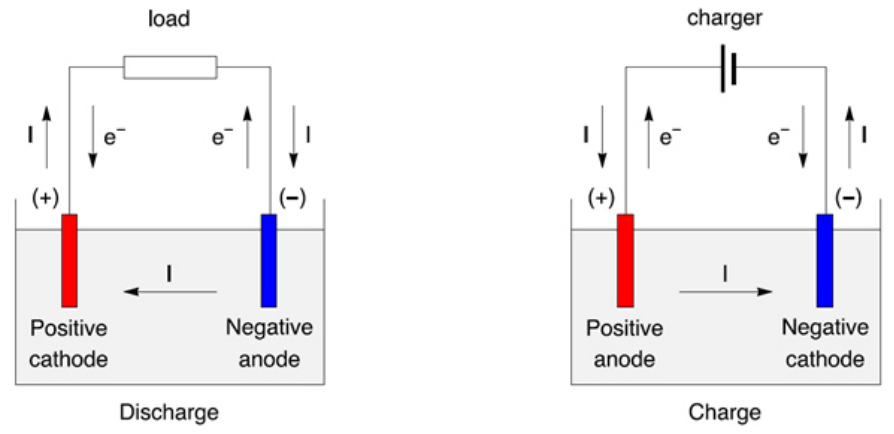

Figure 2. Illustration of a battery system

\subsection{Materials and Equipment}

Salt water as electrolyte water has a potential to be the voltage source to generate power supported by the Exclusive Zone of water. The water should be in neutral condition, which is $\mathrm{PH}=7$ to prevent another factor. Experiments are carried out with small amount of water (100 grams for each experiment), with concentration of salt is in the range between $2 \%$ to $16 \%$. We use two types of water: clean water and distilled water typically used for automobile battery (called "accu water").

$\mathrm{PH}$ level of salt-water mixture is found to be between 6.9-7.0, and PH level of distilled accu water is found to be 0.6. The composition of salt water this experiment will use is $1000 \mathrm{ml}$ of water and $100 \mathrm{gr}$ of salt.

Acrylic as a container has a big role to EESS experiment because, it must hold the water from leaking, otherwise the water will be connected each other effecting the series connection become less. To prevent the leaking situation, rubber sealant is needed to seal every edge of the inside container. The thickness of acrylic used on this project is $3 \mathrm{~mm}$ because it is the optimal thickness for its weight and strength. Also, the material is safe for salt water battery.

\section{Results and Discussion}

This data taking is using $12 \mathrm{v} 3$ watt lamp and $12 \mathrm{v} 16 \mathrm{watt}$ lamp to prove that salt water can be a good power source. For this lamp experiment, there is no another electrical part connected to the lamp. To make sure the data from the experiment is accurate, the experiment must be done over and over again. The number of data taking was 10 times and the data will be taken using voltmeter. The results of voltage are shown in Figure 3. 


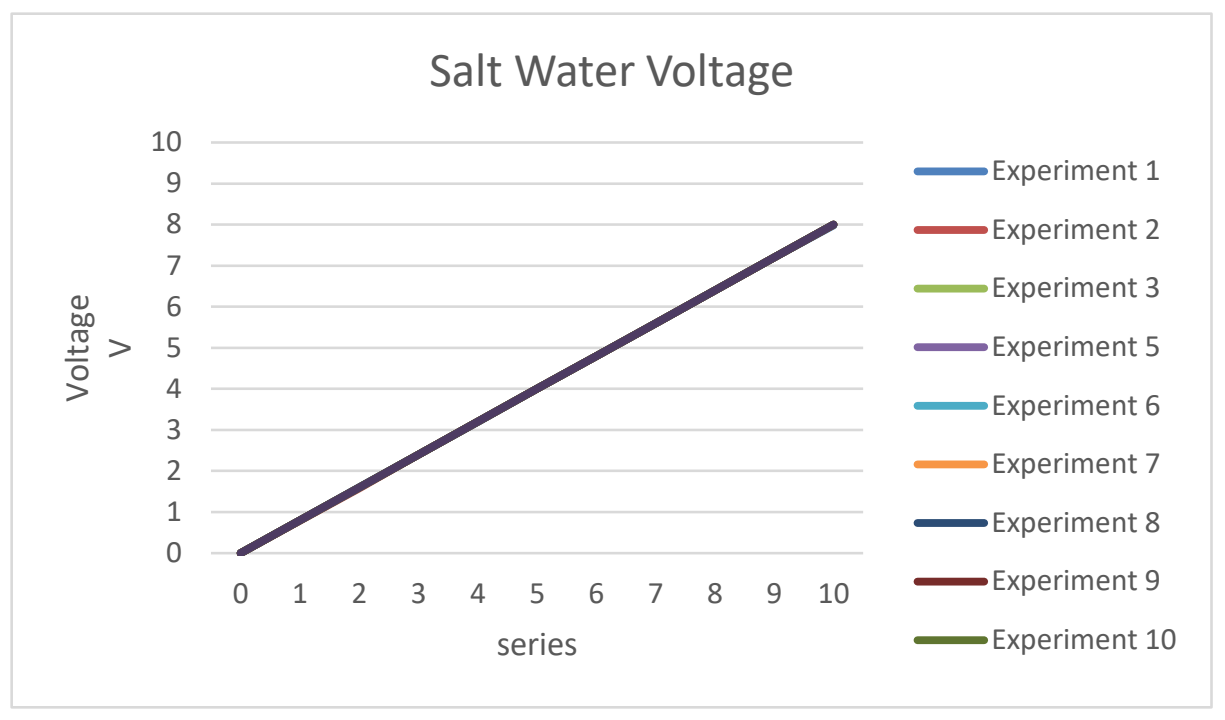

Figure 3. Voltage of Salt Water

The voltage the salt-water get per series is always increasing $0.8 \mathrm{~V}$ which is very good for the voltage source. In order to increase the voltage, the saltwater is heated up under the UV light. The results of current are shown in Figure 4 and Figure 5.

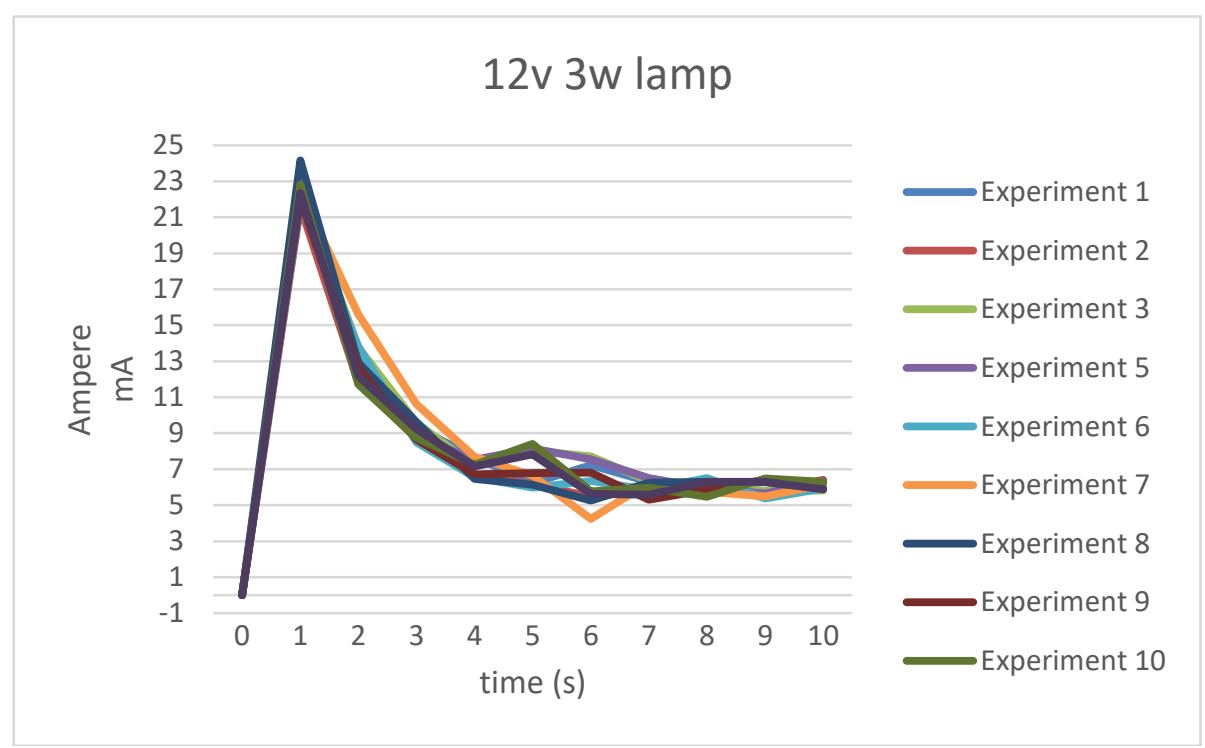

Figure 4. Current Flow Experiment (12v 3W Lamp, Using 6,2v Salt Water

The above preliminary experimental results show that salt-water mixture with concentration between $8 \%$ to $16 \%$ can yield between $0.52-0.53$ Volt, and the result will decrease slowly after 72 hours in storage.

A continued experiment (no. \#4) yield significantly higher voltage, between 5.9-6.3 Volt. And in a series of 10 batteries system, it was recorded to reach a maximum voltage of 8.0 Volt. These results indicate that there is potential for salt-water to be put into practical use. 


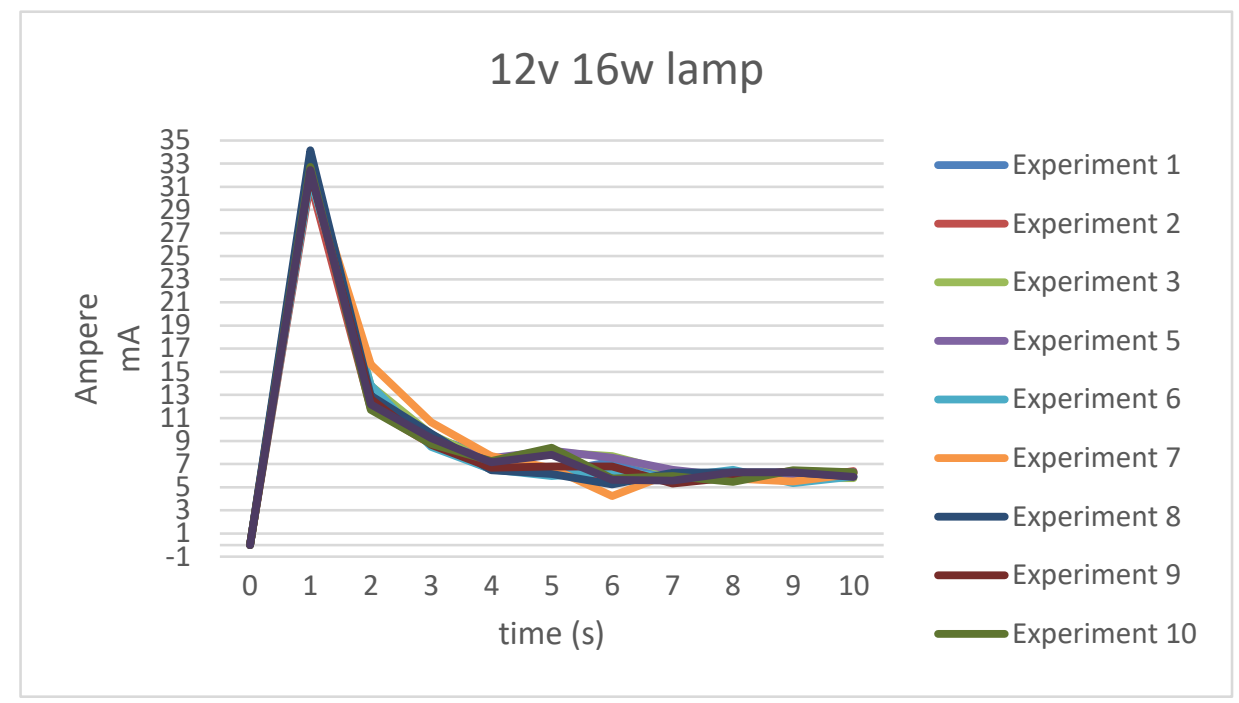

Figure 5. Current Flow Experiment (12v 16W Lamp, Using 6,2v Salt Water)

With regard to possible chemical mechanism, allow us to refer to Kim et al. [8], who suggest a possible electromechanics mechanism of salt-water battery:

At the positive electrode, two possible electrochemical reactions can be considered involving the reduction of water and dissolved oxygen

$$
\begin{array}{lr}
2 \mathrm{H}_{2} \mathrm{O}+\mathrm{O}_{2}+4 \mathrm{e}-\rightarrow 4 \mathrm{OH}- & \mathrm{E}^{0}=0.40 \mathrm{~V} \\
2 \mathrm{H}_{2} \mathrm{O}+2 \mathrm{e}-\rightarrow 2 \mathrm{OH}-+\mathrm{H}_{2} & \mathrm{E}^{0}=-0: 83 \mathrm{~V}
\end{array}
$$

Hence, two possible overall chemical reactions can be constructed, as shown below, when the battery is discharged

$$
\begin{array}{ll}
\mathrm{Na}(\mathrm{s})+1 / 2 \mathrm{H}_{2} \mathrm{O}(\mathrm{l})+1 / 4 \mathrm{O}_{2}(\mathrm{~g}) \rightarrow \mathrm{NaOH}(\mathrm{aq}) & \mathrm{E}=3.11 \mathrm{~V} \\
\mathrm{Na}(\mathrm{s})+\mathrm{H}_{2} \mathrm{O}(\mathrm{l}) \rightarrow \mathrm{NaOH}(\mathrm{aq})+1 / 2 \mathrm{H}_{2}(\mathrm{~g}) & \mathrm{E}=1.88 \mathrm{~V}
\end{array}
$$

While it can be argued that the observed value of around $0.55 \mathrm{~V}$ is in quite agreement with suggested value above of $0.4 \mathrm{~V}$, we recommend that this needs to be investigated further

\section{Conclusions}

From innovation point of view, we consider it is time to begin research not only in conventional renewable energy technologies (like WWS, geothermal etc.), but also in a new type of renewable energy, which we prefer to call: ART (appropriate renewable technologies). In this regard, we can point out a few examples, such as: solar focused power plant or Alfredo Moser's bottle lamp. In recent years, there is also intensive ongoing research in rechargeable seawater battery (SWB).

As a last remark, it is shown that for experiment \#4, we found a quite good result, which yields approximately $0.59 \mathrm{~V}$. That is because in that experiment we use zinc as cathode, and copper as anode. Although so far, we don't find yet any theoretical explanation to support this finding, we consider it as a good sign that salt-water battery with an appropriate choice of electrode can yield excellent result in 
comparison with other types of electric storage such as Li-ion, cadmium, lead-acid, etc. We expect that further experiments may substantiate this finding.

\section{Acknowledgement}

These authors wish to extend sincere gratitude to Swiss-German University, Tangerang, Indonesia, for kind support to this investigation. This report has been presented in SENFA national seminar held at December 2020, host by Padjadjaran University, Bandung. Special thanks to committee of SENFA national seminar.

\section{References}

1. S. Park, B. Senthil Kumar, K. Kim, S.M. Hwang, Y. Kim. 2016 Saltwater as the energy source for low-cost, safe rechargeable batteries. J. Mater. Chem. A, 4, 7207. DOI: 10.1039/c6ta01274d

2. N.A. Bani, M.Z. Hassan, H.M. Kaidi et al. 2018. Feasibility Study of a Low Cost Saltwater Lamp for Rural Area. INTERNATIONAL JOURNAL OF INTEGRATED ENGINEERING VOL. 10 NO. 7, 167-176. DOI: https://doi.org/10.30880/ijie.2018.10.07.016

3. D. Moia, A. Giovannitti, A.A. Szumska et al. 2017. A salt water battery with high stability and charging rates made from solution processed conjugated polymers with polar side chains. arXiv: [1711.10457]

4. F. Smarandache, V. Christianto 2010. Observation of Anomalous Potential Electric Energy in Distilled Water Under Solar Heating, Vixra: 1003.0090

5. G.W. Pollack. Batteries made from water. Proceedings of the NPA. url: http://www.billhowell.ca

6. Allan Widom, John Swain et al. 2015. The theory of water battery. Key engineering materials.

7. Y. Zhang, S.T. Senthilkumar, J. Park, J. Park, Y. Kim. 2018. Batteries \& Supercaps 1, 1-6. DOI: 10.1002/batt.201800012

8. J-K. Kim, E. Lee, H. Kim, C. Johnson, J. Cho, Y. Kim. 2015, Rechargeable Seawater Battery and Its Electrochemical Mechanism. Argonne Scientific Publications, Argonne National Laboratory. url: https://www/anl.gov/argonnescientific-publications/pub/123825

9. Kevin Indra Wijaya. Energy Electric Storage System (EESS) uses electrolyte salt-water. Unpublished bachelor thesis in Mechanical Engineering submitted to Swiss-German University, Tangerang (January 2021). 